\title{
Evaluation and Analysis of China's Eastern Regional Agricultural Competitiveness
}

\author{
RONGPING $-\mathrm{LI}^{[1]}$ \\ Prof, School of Economics \& Business Management, \\ Hebei University of Science \& Technology, \\ Shijiazhuang,China \\ e-mail:1965322@163.com
}

\begin{abstract}
On the basis of a clear definition of the meaning of the competitiveness of agriculture, proposed by four factors, 10 basic indicators constitute agricultural competitiveness evaluation index system, comprehensive evaluation identified by factor analysis, and the use of detailed statistics on the east China 11 agricultural competitiveness provinces empirical evaluation. According to the results of a comprehensive analysis of the provinces, pointing out its strengths and weaknesses and make recommendations for improving the competitiveness of the agricultural provinces.
\end{abstract}

Keywords- Agricultural Competitiveness; Indicator System; Factor analysis; Evaluation and analysis; Conclusions

\section{INTRODUCTION}

With the beginning of the end of China's accession to the WTO and other trade negotiations transition period, China's agriculture is facing stiff competition not only from the international market, the domestic market will also face serious challenges to foreign agricultural products. As a formal member of WTO, China's biggest risk will show the increasingly prominent problem between the issue of agriculture and farmers income.[1] Agriculture is the foundation of our national economy, agriculture competitive strength is directly related to the continued growth of living standards of farmers and overall well-off society. Therefore, improving the competitiveness of agriculture to meet the challenges of economic globalization and regional economic integration, has become an important topic in academia. Based on the connotation of agricultural competitiveness and influence factors based on the discussion of theory, focuses on the discussion of regional agriculture competitiveness of quantitative calculation, quantitative analysis of the provincial agricultural competitiveness of primarily .[2]

\section{THE PRINCIPLE OF AGRICULTURAL} \section{COMPETITIVENESS EVALUATION INDEX SYSTEM}

\section{A. The Meaning and Influencing Factors of Agricultural Competitiveness}

Agricultural Competitiveness can be understood at two levels: the first level is the competitiveness of the agricultural industry, reflected in a country or a region the entire agricultural industry in the international market

\author{
XIAOLING-HUANG ${ }^{[2]}$ \\ Master, School of Economics \& Business Management, \\ Hebei University of Science \& Technology, \\ Shijiazhuang,China \\ e-mail: 852005679@qq.com
}

realities and potential competitiveness. The second level is the competitiveness of farmers and agricultural enterprises produced agricultural products. [3] In general, the factors affecting the level of agricultural development is the factor affecting the competitiveness of agriculture. From the definition of agricultural competitiveness departure, and refer to the relevant literature, which factors attributed to the following four points:

Factors of production: a variety of social resources for social production and management activities needed is to maintain national economic and market fundamentals main production and management process must have. It is the basis for agricultural development, is the fundamental expression of agricultural competitiveness.

Economic benefits: is the measure of all economic activity ultimately comprehensive index. The so-called economic enterprises, enterprises with GDP is proportional relationship between the cost of production. Therefore, agriculture, and only improve the economic efficiency of agriculture, in order to make full use of limited resources to create more products, thereby increasing the competitiveness of agriculture.

Technological innovation capability: technological innovation refers to new technologies (new products, new technology) research and development, production and commercialization of technology-related economic activity, is an important part of technological progress. Technological innovation is the key to winning industrial competitiveness, but also an important indicator to measure the competitiveness of agriculture.

Market Competitiveness: competitiveness is mainly reflected in the ability to develop new markets and product competitiveness, the present study as a primary target. Refers to the ability of enterprises to develop new markets for their products to gain market has recognized the reality and potential capacity, it is the fundamental guarantee for the ultimate purpose of the business can be realized.

\section{B. The Evaluation Index System of Agricultural Competitiveness}

According to the analysis of the factors affecting industrial competitiveness, [4] taking into account the evaluation of targeted, systemic, operability and objectivity, the paper was founded by four eastern provinces agricultural competitiveness level indicators, 
China consisting of 10 secondary indicators evaluation index system, see Table 1 .

TABLE I AGRICULTURAL COMPETITIVENESS EVALUATION INDEX SYSTEM

\begin{tabular}{|c|c|}
\hline Level index & Secondary index \\
\hline \multirow{3}{*}{ Factor of production } & $\begin{array}{l}\text { 1. agriculture, forestry, animal husbandry and } \\
\text { fishery output value ( one hundred million } \\
\text { yuan) }\end{array}$ \\
\hline & $\begin{array}{l}\text { 2. effective irrigation area ( one thousand } \\
\text { hectares) }\end{array}$ \\
\hline & $\begin{array}{l}\text { 3. the total power of agricultural machinery } \\
\text { (ten thousand kilowatts) }\end{array}$ \\
\hline \multirow{3}{*}{ Economic benefit } & 4. labor productivity (\%) \\
\hline & 5. land productivity $(\%)$ \\
\hline & 6. rural per capita household income（yuan） \\
\hline \multirow{2}{*}{$\begin{array}{c}\text { Technological } \\
\text { innovation capability }\end{array}$} & $\begin{array}{l}\text { 7. agricultural technicians ( ten thousand } \\
\text { people) }\end{array}$ \\
\hline & $\begin{array}{ll}\text { 8. comprehensive agricultural development } \\
\text { investment intensity }(\%)\end{array}$ \\
\hline \multirow{2}{*}{$\begin{array}{l}\text { Market } \\
\text { competitiveness }\end{array}$} & $\begin{array}{l}\text { 9. the growth rate of investment in fixed assets } \\
(\%)\end{array}$ \\
\hline & $\begin{array}{l}10 \text {. increase the value of agricultural output } \\
\text { growth }(\%)\end{array}$ \\
\hline
\end{tabular}

\section{EVALUATION MODELS OF AGRICULTURE COMPETITIVENESS GRICULTURE COMPETITIVENESS}

China's eastern provinces to evaluate the competitiveness of agriculture, which aims to classify the 10 evaluation for a few elements, sorted according to the few elements of the score. therefore, it is suitable for factor analysis.

Factor analysis is a study by the inter-relationship between the internal multivariate covariance matrix or matrix dependence, according to the correlation between the size of the variable packet so that between the same set of variables with a strong correlation between a weak correlation between different sets of variables. Each group represents a basic structure, called the common factor, undetectable by the least amount of common factors with a linear function of the variables and specific factors described in the original observations. The mathematical model is as follows:

Suppose $\mathrm{n}$ samples, each sample was observed variables $\mathrm{p}$, denoted by $\mathrm{x} 1, \mathrm{x} 2, \ldots \mathrm{xp}$ (for simplicity, you can set xi mean 0 and variance 1) to give each of the original variables $\mathrm{k}(\mathrm{k}<\mathrm{p})$ factors $\mathrm{F} 1, \mathrm{~F} 2, \mathrm{~F} 3, \ldots, \mathrm{Fk}$ is a linear combination:

$$
\left\{\begin{array}{c}
x_{1}=a_{11} F_{1}+a_{12} F_{2}+\mathrm{L}+a_{1 k} F_{k}+\zeta_{1} \\
X_{2}=a_{21} F_{1}+a_{22} F_{2}+\mathrm{L}+a_{2 k} F_{k}+\zeta_{2} \\
\mathrm{M} \\
X_{p}=a_{m 1} F_{1}+a_{m 2} F_{2}+\mathrm{L}+a_{p k} F_{k}+\zeta_{p}
\end{array}\right.
$$

(1) is a mathematical model of factor analysis, can also be expressed in matrix form as:

$$
X=A F+\zeta
$$

$\mathrm{F}$ is called common factors are all common factor appears in the expression of various original observed variables are mutually independent theoretical unobservable variables; called a special factor, is the vector A unique factor. Formula (1) in the matrix $A=($ aij) of the elements aij called factor loading, aij larger the absolute value, indicating the greater the degree of dependence of $\mathrm{xi}$ and $\mathrm{Fj}$.

In table 1 agricultural competitiveness evaluation index, the 10 indicators used in the production factors, economic, technological innovation capacity and market competitiveness are positive indicators, without the need for a positive process. In order to eliminate the influence of the index between the dimensionless, It should need nondimensionalized treatment for each index. The method is to improve the efficiency coefficient .Formulas is (3):

$$
Z_{i}=\frac{x_{i}-x_{i}^{s}}{x_{i}^{h}-x_{i}^{s}} \times 40+60
$$

$x_{i}$ represents the first indicator of value, $x_{i}^{s}$ and $x_{i}^{h}$ $x_{i}^{h}$

\section{EMPIRICAL EVALUATION AND ANALYSIS OF AGRICULTURAL COMPETITIVENESS}

The raw data used in this paper come from "China Statistical Yearbook 2013",[5] evaluated for 11 provinces in eastern China, data for industrial enterprises above designated size caliber.,The article uses factor analysis in the eastern provinces to evaluate the competitiveness of agriculture and analysis by application SPSS16.0.

\section{A. Factor Analysis of the Applicability of Test}

In this paper, the calculation Bartlett sphericity KMO test and inspection methods to detect the applicability of factor analysis. KMO and Bartlett's test of sphericity test results shown in Table 2. [6]

Bartlett sphericity test showed: Bartlett is $81.684, \mathrm{P}$ value close to zero, if the significance level of 0.01 , reject the correlation matrix for the matrix of the null hypothesis that there is a significant difference in the correlation matrix and the matrix, consider factor analysis.[7] Seen from Table 2, KMO value is 0.613 , the original indicator variables can be factor analysis.

\section{TABLE II KMO AND BARTLETT 'S TEST}

\begin{tabular}{|c|c|c|}
\hline \multicolumn{2}{|c|}{$\begin{array}{c}\text { Kaiser-Meyer-Olkin Measure of Sampling } \\
\text { Adequacy. }\end{array}$} & .613 \\
\hline \multirow{3}{*}{$\begin{array}{c}\text { Bartlett's Test of } \\
\text { Sphericity }\end{array}$} & Approx. Chi-Square & 81.684 \\
\cline { 2 - 3 } & df & 45 \\
\cline { 2 - 3 } & Sig. & .001 \\
\hline
\end{tabular}

\section{B. The Main Calculation Steps and Results}

\section{1) Factor extraction}

As seen from Table 3, in accordance with the correlation matrix eigenvalues greater than 1 standard, from the original 10 statistical indicators can be extracted three main 
factors, the cumulative total of the three main factors explain the variance reached $87.306 \%$, the number of factors to meet cumulative contribution requirements.

TABLE III TOTAL VARIANCE EXPLAINED

\begin{tabular}{|c|c|c|c|c|c|c|}
\hline \multirow{2}{*}{ Component } & \multicolumn{3}{|c|}{ Initial Eigenvalues } & \multicolumn{2}{c|}{$\begin{array}{c}\text { Extraction Sums of Squared } \\
\text { Loadings }\end{array}$} \\
\cline { 2 - 7 } & \multirow{2}{*}{$\begin{array}{c}\text { Total } \\
\text { \% of } \\
\text { Variance }\end{array}$} & Cumulative \% & Total & \multicolumn{2}{c|}{$\begin{array}{c}\text { \% of } \\
\text { Variance }\end{array}$} & \\
\hline 1 & 5.023 & 50.233 & 50.233 & 5.023 & 50.233 & 50.233 \\
\hline 2 & 2.248 & 22.476 & 72.708 & 2.248 & 22.476 & 72.708 \\
\hline 3 & 1.460 & 14.598 & 87.306 & 1.460 & 14.598 & 87.306 \\
\hline 4 & .561 & 5.612 & 92.919 & & & \\
\hline 5 & .383 & 3.832 & 96.751 & & & \\
\hline 6 & .122 & 1.218 & 97.969 & & & \\
\hline 7 & .097 & .973 & 98.943 & & & \\
\hline 8 & .052 & .525 & 99.468 & & & \\
\hline 9 & .045 & .448 & 99.916 & & & \\
\hline 10 & .008 & .084 & 100.000 & & & \\
\hline
\end{tabular}

TABLE IV ROTATED COMPONENT MATRIX

\begin{tabular}{|c|c|c|c|}
\hline \multirow{2}{*}{ Index } & \multicolumn{3}{|c|}{ Component } \\
\cline { 2 - 4 } & 1 & 2 & 3 \\
\hline $\begin{array}{c}\text { effective } \\
\text { irrigation area }\end{array}$ & .968 & .968 & .968 \\
\hline $\begin{array}{c}\text { agriculture, } \\
\text { forestry, animal } \\
\text { husbandry and } \\
\text { fishery output } \\
\text { value }\end{array}$ & .928 & .928 & .928 \\
\hline $\begin{array}{c}\text { the total power } \\
\text { of agricultural } \\
\text { machinery }\end{array}$ & .905 & .905 & .905 \\
\hline $\begin{array}{c}\text { comprehensive } \\
\text { agricultural } \\
\text { development } \\
\text { investment } \\
\text { intensity }\end{array}$ & .895 & .895 & .895 \\
\hline $\begin{array}{c}\text { rural per capita } \\
\text { household } \\
\text { income }\end{array}$ & -.360 & -.360 & -.360 \\
\hline $\begin{array}{c}\text { the growth rate } \\
\text { of investment in } \\
\text { fixed assets }\end{array}$ & -.104 & -.104 & -.104 \\
\hline $\begin{array}{c}\text { labor } \\
\text { productivity }\end{array}$ & -.484 & -.484 & -.484 \\
\hline $\begin{array}{c}\text { agricultural } \\
\text { technicians }\end{array}$ & -.324 & -.324 & -.324 \\
\hline $\begin{array}{c}\text { land } \\
\text { productivity }\end{array}$ & -.017 & -.017 & -.017 \\
\hline $\begin{array}{c}\text { increase the } \\
\text { value of } \\
\text { agricultural } \\
\text { output growth }\end{array}$ & .009 & .009 & .009 \\
\hline $\begin{array}{c}2 \\
2 \text { ) Factor }\end{array}$ & $10 t a t i 0 n$ & \\
\hline
\end{tabular}

2) Factor rotation

To facilitate interpretation of the main factors, the article can whirl for loading matrix rotation. Table 4 is rotated after the factor loading matrix.As can be seen from Table 4:

a) the effective irrigation area of agriculture, forestry, animal husbandry and fishery output, the total power of agricultural machinery, agricultural comprehensive development investment strength index has a larger load on factor 1 , can be named as a dominant factor agricultural competitiveness.

b) rural per capita household income, the growth rate of investment in fixed assets, labor productivity, agricultural technicians index has a greater load on the factor of 2, can be named as a potential factor of two agricultural competitiveness.

c) land productivity, increase the value of agricultural output growth targets larger loads can be named as agricultural efficiency factor of 3 in 3 competitive factor.

3) Factor score

Regression coefficient estimate factor scores, factor score coefficient matrix is calculated as shown in Table 5.

TABLE V COMPOENT SCORE COEFFICIENT MATRIX

\begin{tabular}{|c|c|c|c|}
\hline & \multicolumn{3}{|c|}{ Component } \\
\hline & 1 & 2 & 3 \\
\hline $\begin{array}{c}\text { agriculture, forestry, animal husbandry and } \\
\text { fishery output value }\end{array}$ & .248 & .026 & -.004 \\
\hline effective irrigation area & .277 & .074 & -.025 \\
\hline the total power of agricultural machinery & .247 & .014 & -.138 \\
\hline labor productivity & -.034 & .287 & .183 \\
\hline land productivity & .014 & .159 & .551 \\
\hline rural per capita household income & .015 & .294 & -.028 \\
\hline agricultural technicians & -.004 & .189 & -.163 \\
\hline $\begin{array}{c}\text { comprehensive agricultural development } \\
\text { investment intensity }\end{array}$ & .280 & .179 & .191 \\
\hline the growth rate of investment in fixed assets & -.160 & -.397 & -.123 \\
\hline $\begin{array}{l}\text { increase the value of agricultural output } \\
\text { growth }\end{array}$ & -.066 & -.115 & .381 \\
\hline
\end{tabular}

Assuming bi indicator variables for the $\mathrm{i}$-th provinces normalized, $\mathrm{i}=(1, \ldots, 11)$; cj $\mathrm{j}$ th factor score coefficient vector, $\mathrm{j}=(1,2,3)$, this vector by twiddle factor loading matrix available. The provinces in the $\mathrm{j}$-th factor score: $\mathrm{Fj}$ $=b j \times c j .[8]$ Take the variance contribution of each factor scores for weight composite factor scores derived provinces. The formula: $\mathrm{W}=0.575 \times \mathrm{F} 1+0.258 \times \mathrm{F} 2+0.167 \times$ F3

According to provincial and municipal comprehensive factor scores derived provinces agricultural competitiveness ranking, as shown in Table 6: 
TABLE VI COMPETITIVE FACTORS IN THE EASTERN PROVINCES OF AGRICULTURE AND THE EVALUATION SCORES AND RANKINGS

\begin{tabular}{|c|c|c|c|c|c|c|c|c|}
\hline \multirow{2}{*}{ Province } & \multicolumn{2}{|c|}{ Overt competitiveness } & \multicolumn{2}{l|}{ Potential competitiveness } & \multicolumn{2}{l|}{ Benefits competitiveness } & \multicolumn{2}{c|}{ Overall competitiveness } \\
\cline { 2 - 9 } & score & ranking & score & ranking & score & ranking & Total score & ranking \\
\hline Beijing & -0.81783 & 9 & 0.93204 & 2 & -1.45318 & 11 & -0.47247 & 8 \\
\hline Tianjin & -0.77766 & 8 & 0.09302 & 5 & -1.16113 & 9 & -0.61706 & 10 \\
\hline Hebei & 1.17339 & 2 & -0.64682 & 9 & -0.16053 & 7 & 0.48101 & 3 \\
\hline Liaoning & 0.19859 & 4 & -0.03376 & 6 & 0.98764 & 2 & 0.27042 & 5 \\
\hline Shanghai & -0.92418 & 10 & 1.66833 & 1 & 0.18045 & 6 & -0.07084 & 6 \\
\hline Jiangsu & 1.07757 & 3 & 0.78215 & 3 & 1.29225 & 1 & 1.03720 & 1 \\
\hline Zhejiang & 0.14968 & 5 & 0.75725 & 4 & 0.75058 & 4 & 0.40678 & 4 \\
\hline Fujian & -0.39483 & 7 & -0.31220 & 8 & 0.67353 & 5 & -0.19510 & 7 \\
\hline Shandond & 1.82740 & 1 & -0.27808 & 7 & -1.18651 & 10 & 0.78086 & 2 \\
\hline Guangdong & -0.19308 & 6 & -1.18666 & 10 & -0.80077 & 8 & -0.55091 & 9 \\
\hline Hainan & -1.31906 & 11 & -1.77529 & 11 & 0.87767 & 3 & -1.06991 & 11 \\
\hline
\end{tabular}

From the geographical distribution: the top four

\section{Comprehensive Evaluation and Analysis}

1 ) Overall, the Eastern Regional Agricultural Competitiveness fundamental equilibrium distribution

Obtained from Table 6, 2012, 11 provinces and cities in eastern agricultural competitiveness average score of 0 points, poor score of 2.10 points. 11 provinces and cities, higher than the average score has five provinces, namely: Hebei, Liaoning, Jiangsu, Zhejiang and Shandong, Jiangsu, where a score of 1.0372 points, much higher than the provincial average of 11 ; lower than average there are six provinces, namely: Beijing, Tianjin, Shanghai, Fujian, Guangdong and Hainan, which has a score of less than 0.5 points, Tianjin, Guangdong and Hainan three provinces. This shows that 11 provinces agricultural competitiveness substantially uniform distribution of the mean scores on both sides.

2 ) From the spatial distribution, the eastern provinces and the competitiveness of agriculture in general presentation south than in the north of the distribution

First category of highly competitive industrial cities of Jiangsu, Shandong and Hebei, Zhejiang, 0.6765 average score points, base, overall strength, especially strong dominant agricultural competitiveness; second industry more competitive the provinces of Liaoning, Shanghai, Fujian, average score of -0.0015 points, including Liaoning, highly competitive benefits in agriculture, industrial competitiveness potential Shanghai ranked first, while Fujian is relatively weak in all respects; the third category agriculture weak competitiveness of cities are Beijing, Guangdong, Tianjin, Hainan, average score of 0.6776 points, the four provinces of the competitiveness of agriculture as a whole is weak. For this four provinces, Beijing and Tianjin is stronger in potential agricultural competitiveness, Hainan highly competitive agricultural efficiency. provinces, the South accounted for two, namely,

Jiangsu and Zhejiang; north accounted for two, namely, Shandong and Hebei; competitiveness of the top six provinces, the South accounted for four, namely, Jiangsu, Zhejiang, Shanghai and Fujian. And the average score of the top four provinces of 0.6765 , which was much higher than the overall average. Eastern provinces and the competitiveness of agriculture in the south than in the north showing the geographical distribution of the low distribution. Provincial agricultural competitiveness is gap.

3) From the factor comparison, the profitability of agriculture in eastern provinces is not high, lack of development potential

By Table 6 can be drawn: 11 provinces and cities in the dominant agricultural competitiveness score higher than the overall competitiveness ranking score ranking has three provinces, there is a flat, low seven provinces; agricultural potential competition force higher overall competitiveness ranking has four provinces, seven provinces have low; agricultural efficiency competitiveness ranking higher than the overall competitiveness of the provinces have six, there are five low; dominant agricultural competitiveness score ranked higher than the potential competitiveness of agriculture has six provinces, there is a flat, low has four. Shows the eastern provinces of the potential lack of competitiveness of agriculture, the development potential is not strong, it will affect further enhance the comprehensive competitiveness.

\section{CONCLUSIONS AND RECOMMENDATIONS}

Seen from the results of the factor analysis, 11 provinces on three factors have reflected the strength of the agricultural competitiveness. Thus increasing the competitiveness of the agricultural provinces, it is necessary to strengthen the three areas from.[9] And to implement this, we need to optimize the agricultural structure, upgrade the industry. The only way to enhance the competitiveness of agriculture in eastern regions is to 
enhance the level of competitiveness of agriculture as a whole.

1) The competitiveness of agriculture in eastern provinces of generally south than in the north of the distribution, over time, is not conducive to the development of agriculture in the eastern region. Therefore from the government's point of view, to increase financial support for agricultural science and technology, establish and improve agricultural technology innovation system. And led by the Government to introduce and cultivate high-level agricultural science and technology talent.

2) Jiangsu, Shandong, Hebei, Zhejiang four provinces should make full use of its competitive advantages, and strive to foster the growth of leading agricultural enterprises. One is based on the existing resources, to initiate and support the circulation of agricultural enterprises; the second is the development of policies to guide the non-farm business investment, the agricultural production and processing, sales, service and other sectors closely linked to the implementation of integrated operation.[10]

3) Beijing, Guangdong, Tianjin and Hainan provinces in agriculture less competitive areas should exploit its comparative advantages, weaknesses, improve professional competence. In addition, not only to the introduction of foreign technology and machinery to transform, but to nurture new farmers, improve labor productivity and economies of scale, thus enhancing the competitiveness of agriculture.

\section{REFERENCES}

[1] Zhang Haihong, "A comparative stury of Chinese regional agricultural competitiveness," [J] China's agriculture notified, 2012(18),pp. 165-170,

[2] Du Huazhang, "Jiangsu county agriculture competitiveness evaluation based on factor analysis," [J] Journal of Agricultural Management Institute of Ministry of Agriculture „Jan.2011, pp. 1721.

[3] Su Hang,"Chinese agricultural competitiveness connotation definition , "[J] ecological economy, 2004 (5),pp. 37-39.

[4] Liu Feixiang and Pan Guoliang, “ Index evaluation and fujian agricultural competitiveness dynamic analysis, " $[\mathrm{J}]$ China agriculture bulletin, 2009, 25 (18) : 494-499

[5] "He bei province bureau of statistics. Hebei statistical yearbook, 2012, , [M] Beijing: China statistics Press, 2012

[6] Xia Yifan edited. SPSS Essentials statistical analysis and detailed examples [M] Beijing: Electronic Industry Press, 2010 (1).pp.231236.

[7] Li Ming, Huang Shanyan and Liu Yujia., "Chengdu Industrial Competitiveness," [J] Statistics and Decision, 2011 (18).pp.132135.

[8] Xue Xuandeng and Wang XiaoYan, "Based on principal component analysis of henan agricultural competitiveness evaluation research, "[J]Shanxi Agric.Univ.(Social Science Edition) No.11 Vol.13 2014.

[9] Liu Ai-jun , Zhang Zhen and Ding Zhenjiang. “ Try to talk about modern agriculture development strategy in jiangsu," [J]Jiangxi agricultural journal, 2008, (6) : 191-121

[10] Qu Lei, "Shanxi Province agricultural competitiveness evaluation research," [D]Taiyuan, shanxi university of finance and economics, 2012 . 